\title{
Efficacy of Topical 5\% Acyclovir-1\% Hydrocortisone Cream (ME-609) for Treatment of Herpes Labialis: a systematic review
}

\author{
MARIA INÊS DA ROSA ${ }^{1}$, SUÉLI L. SOUZA ${ }^{1}$, BRUNA F. DE FARIAS ${ }^{1}$, PATRÍCIA D.S. \\ PIRES $^{2}$, EDUARDO R. DONDOSSOLA ${ }^{1}$ and MARIA EDUARDA F. DOS REIS ${ }^{3}$ \\ ${ }^{1}$ Laboratory of Epidemiology of University of Extremo Sul Catarinense, \\ Avenida Universitária, 1105, Bairro Universitário, 88806-000 Criciúma, SC, Brazil \\ ${ }^{2}$ University of the Extreme South of Santa Catarina, Teacher of Dental of University of \\ Extremo Sul Catarinense, Avenida Universitária, 1105, Bairro Universitário, 88806-000 Criciúma, SC, Brazil \\ ${ }^{3}$ Veterinary Medical, Laboratory of Epidemiology of University of Extremo Sul Catarinense, \\ Avenida Universitária, 1105, Bairro Universitário, 88806-000 Criciúma, SC, Brazil \\ Manuscript received on December 18, 2014; accepted for publication on April 3, 2015
}

\begin{abstract}
We performed a systematic review with the objective of verifying the efficacy of topical use $5 \%$ Acyclovir-1\% Hydrocortisone cream compared to the placebo group for herpes simplex labialis treatment. We performed a literature search using MEDLINE, Embase, BIOSIS, LILACS, Scopus, Grey literature, the Cochrane Central Register of Controlled Trials, the ISI Web of Science and IBECS from 1990 to June 2014. We reported the outcomes using relative risk (RR) with 95\% confidence intervals. The literature search yielded 180 potentially relevant publications. Reviews of the reference lists yielded two further citations. Among these papers, two were considered eligible for inclusion in this review. Both trials included 1,213 patients. A meta-analysis of these studies showed a $\mathrm{RR}=0.77$, (95\% CI 0.70-0.86; $\mathrm{p}<0.001)$. This result suggests that an early episodic treatment with the combination of an antiviral and a steroid is beneficial for herpes simplex labialis treatment.
\end{abstract}

Key words: Acyclovir, Herpes Labialis, Hydrocortisone, ME-609, Systematic Review.

\section{INTRODUCTION}

Herpes simplex labialis (HSL) occurs in $20 \%$ to $40 \%$ of the general population. Approximately onethird of all infected patients suffer relapses (Embil et al. 1975).

Two strains of herpes simplex viruses have been identified, including HSV-1 and HSV-2. HSV-1 is mainly implicated in orofacial infections,

Correspondence to: Maria Inês da Rosa

E-mail: mir@unesc.net whereas HSV-2 is predominantly associated with genital lesions (Wald et al. 2004).

Following the primary infection in the oral cavity, often occurring at an early age, the virus establishes a chronic, latent and life-long infection in the sensory ganglia, predominantly in the trigeminal ganglion (Whitley and Roizman 2001).

Symptomatic cases are characterized by a prodromal period with itching and stinging, erythema (macule), papule, vesicle, ulcer or soft crust, hard crust, residual abnormalities (dry 
flaking skin and residual swelling and erythema), and re-epithelialization and healing (normal skin) (Spruance et al. 1977, Whitley and Roizman 2001).

In healthy individuals, the condition is selflimiting over 7 to14 days (Sciubba 2003).

Despite many advances in antiviral therapy for recurrent herpes labialis in immunocompetent patients, the treatment remains controversial. The development of novel strategies to eradicate herpes simplex virus is a global public health priority.

We have performed a systematic review including all randomized controlled trials which used topical 5\% Acyclovir-1\% Hydrocortisone cream compared to the placebo group for herpes simplex labialis treatment.

\section{MATERIALS AND METHODS}

The PRISMA guidelines were followed for this metaanalysis of randomized trials (Liberati et al. 2009).

\section{INCLUSION AND EXCLUSION CRITERIA}

To be eligible for inclusion in our systematic review, studies had to examine specific treatments with Topical 5\% Acyclovir-1\% Hydrocortisone Cream (ME-609) for Herpes Labialis in comparison with the topical placebo group. Only randomized trials were included.

\section{SEARCH STRATEGY}

We performed a literature search using MEDLINE, Embase, BIOSIS, LILACS, Scopus, Grey literature, the Cochrane Central Register of Controlled Trials, the ISI Web of Science and IBECS from 1990 to June 2014). We first derived 3 themes that were combined with the Boolean operator "AND". Each theme was created with the Boolean operator "OR" to search for terms appearing as either exploded medical headings (MeSH) or text words. The first theme was "randomized control trial"; the second theme was "Herpes Labialis" and the third was " $5 \%$ Acyclovir-1\% Hydrocortisone Cream" "ME-609”. We then manually scanned the reference lists of all the identified articles. There were no restrictions placed on the language of the publications.

\section{DATA EXTRACTION}

Multiple teams of two reviewers (M.I.R and P.D.P) independently screened the title, abstract, and key words of each reference identified by the search and applied the inclusion and exclusion criteria. The same procedure was applied to full text articles and potentially eligible references. Differences in the reviewers' opinions were resolved by discussion or by a third reviewer. Data on quality, patient characteristics, interventions, and relevant outcomes were independently abstracted by two reviewers (S.L.S. and B.F.F).

Bias risk was assessed by considering the adequacy of randomization and allocation concealment, and the comparability of the women in the different study groups. The main outcome was the development of ulcerative lesions.

\section{STATISTICAL ANALYSIS}

We measured the inter-rater agreement for study inclusion and methodological quality assessment (weighted $\kappa$ ) (DerSimonian and Laird 1986). We reported the outcomes using relative risk (RR) with $95 \%$ confidence intervals (CIs). Pooled-effect estimates were derived using a random-effects model with Mantel-Haenszel statistics. Study heterogeneity was determined using the $I^{2}$ statistic, in which numbers greater than $75 \%$ suggest considerable heterogeneity (DerSimonian and Laird 1986), and $P$ values from the $\chi^{2}$ test. In cases of considerable heterogeneity, no pooled estimate was provided. A sensitivity analysis was planned a priori to compare the results, the designs and to report the quality of the studies; we focused on studies that were defined as "good quality" (Deeks et al. 2008).

Meta-analyses were performed using Review Manager Version 5.0.17 software (2008) (Nordic Cochrane Center, Copenhagen, Denmark). 


\section{RESULTS}

The literature search yielded 180 potentially relevant publications. Reviews of the reference lists yielded two further citations. Among these papers, two were considered eligible for inclusion in this review (Fig. 1). The inter-rater reliability for study selection was good $(\kappa=0.9)$.

Both trials included 1,213 patients (791 in the experimental group and 422 in the control group).

The studies included were published in English. Table I shows the details of the studied populations, interventions, outcome assessments, and data reporting. The assessment of quality studies are presented in Figure 2, showing low risk of bias.
A meta-analysis of these studies (Evans 2002, Hull 2011) showed that treatments with Topical 5\% Acyclovir-1\% Hydrocortisone Cream (ME609 ) has a significant positive effect on developed ulcerative lesions compared with placebo patients. (RR 0.78, 95\% CI 0.70-0.85; p<0.001) (Fig. 3).

The heterogeneity was checked by $\mathrm{Chi}^{2}$ test, which produced $\mathrm{P}$ value of 0.57 and $\mathrm{I}^{2}=0 \%$. No heterogeneity was detected in either? studies. The funnel plot was not shown because only two studies were included in the meta-analysis.

\section{DISCUSSION}

This review compared the effectiveness of Acyclovir/hydrocortisone topical in reducing clinical

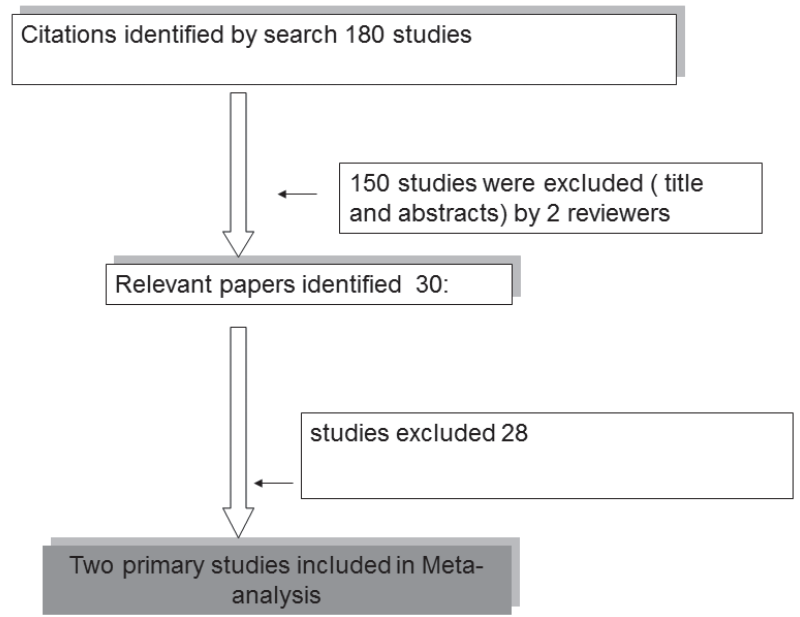

Figure 1 - Study selection process.

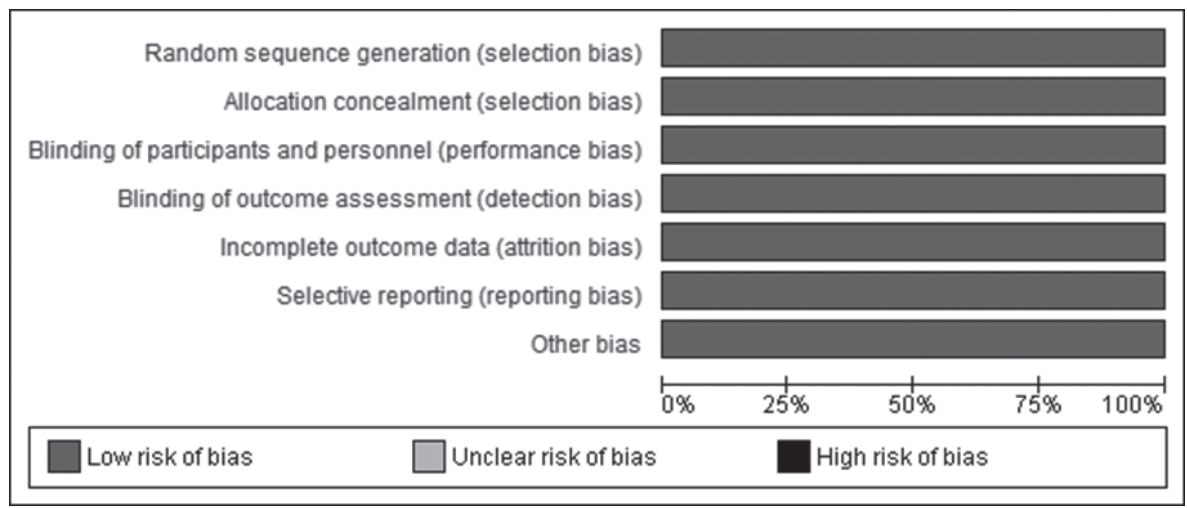

Figure 2 - Forest Plot showing the meta-analysis of uses of Topical 5\% Acyclovir-1\% Hydrocortisone Cream (ME-609) versus placebo for the treatment of Herpes Labialis. 


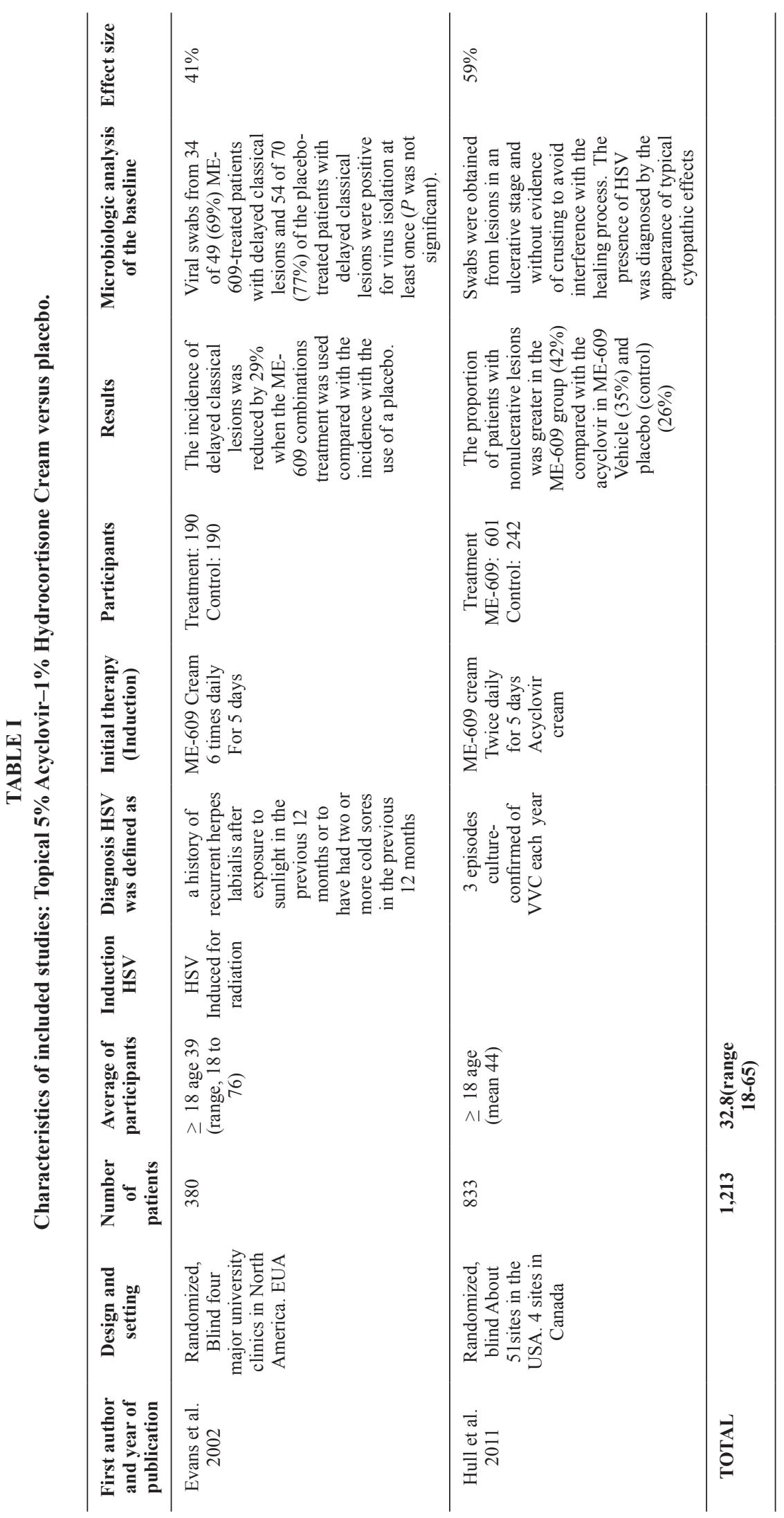




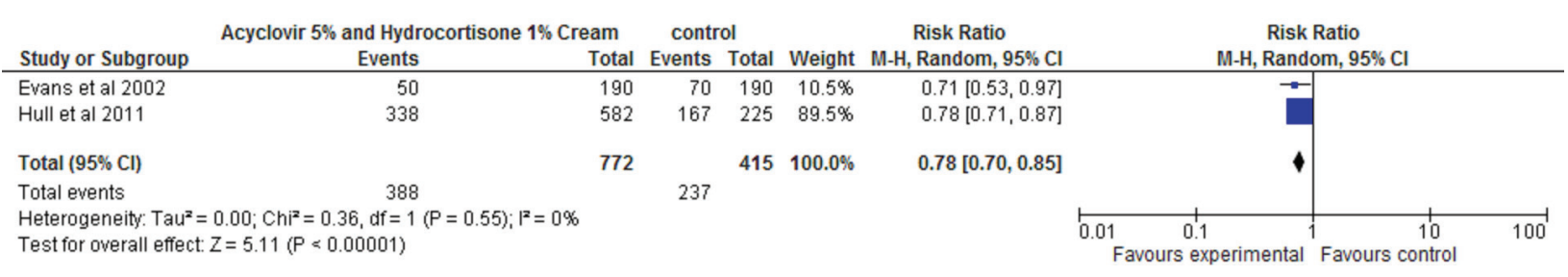

Figure 3 - Assessment of study quality.

recurrence of herpes simplex labialis. Only two studies which met the criteria of the research were found. The results showed a statistically significant difference between Acyclovir/hydrocortisone topical versus placebo in the development decrease of the ulcerative lesions of herpes simplex labialis.

Acyclovir/hydrocortisone topical (5\% acyclovir and $1 \%$ hydrocortisone) was approved by the FDA in 2009 for recurrent herpes simplex labialis (FDA 2012).

Acyclovir (9-[2-hydroxyethoxymethyl] is an acyclic nucleoside analogue of guanosine. The drug was synthesized by Howard Schaeffer, and found to have potent in vitro antiviral activity against herpes simplex virus type 1 (Balfour Jr et al. 1983).

The selective activity of acyclovir for cells infected with herpes viruses is due to the production of two unique herpes-specific enzymes, an isofunctional deoxynucleoside kinase (usually referred to as the herpes-specific thymidine kinase) and a herpes-specific DNA polymerase (Elion 1982). Acyclovir inhibits viral replication in two ways. First, acyclovir triphosphate inhibits the incorporation of deoxynucleotide triphosphates into herpes virus DNA. Second, the triphosphorylated drug is incorporated into newly formed herpes virus DNA (Elion 1982, Laskin 1983).

Hydrocortisone is the main glucocorticoid secreted by the adrenal cortex. It is used topically for its anti-inflammatory effects which suppress the clinical manifestations of the disease in a wide range of disorders where inflammation is a prominent feature (Brazzini and Pimpinelli 2002).

The use of a mild corticosteroid, such as hydrocortisone, in combination with acyclovir, appears to alter the clinical course of herpes labialis for a sizeable proportion of the patients. This naturally opens the way for further improvements in the future, when more potent corticosteroids, as well as corticosteroids with different properties could be tested (Harmenberg et al. 2010).

A study in animal models of HSV infection showed that topical treatment with ME-609 (which contains 5\% acyclovir and $1 \%$ hydrocortisone) in the ATI mouse model was substantially more efficacious than $5 \%$ Zovirax ${ }^{\circledR}$ cream, $1 \%$ hydrocortisone or no treatment, respectively. The beneficial properties of ME-609 were also found to be superior to those of Zovirax ${ }^{\circledR}$ cream when tested in the standard guinea pig model, representing a primary HSV infection (Harmenberg et al. 2003).

In the Hull and co-workers study, patients receiving ME-609, 42\% did not develop an ulcerative lesion compared with $26 \%$ of patients receiving placebo $(\mathrm{P} \backslash .0001)$. In Evans and co-workers, the main result of double blind randomized study was that $29 \%$ fewer patients in the combination treatment group developed ulcerative lesions compared with placebo patients.

This meta-analysis complied with the criteria for performing a rigorous systematic review planed a priori. This included the use of study quality assessment and investigation of results by random effect models to test the robustness of the results. The potential limitations of this systematic review were the small number of studies included.

Our results showed that $23 \%$ less patients in the treatment group developed ulcerative lesions compared with placebo patients. The results from this meta-analysis suggested that an early episodic treatment with the combination of an antiviral and a steroid is beneficial, indicating that the association 
of an antiviral and corticosteroid therapy may have additive effects. The vasoconstriction mediated by steroid would increase the dermal concentration of the antiviral.

\section{RESUMO}

Realizamos uma revisão sistemática com o objetivo de verificar a eficácia do uso tópico de aciclovir 5\% e Creme de hidrocortisona $1 \%$ em comparação com o grupo placebo para o tratamento herpes labial simplex. Realizamos uma pesquisa bibliográfica usando o Medline, Embase, BIOSIS, LILACS, Scopus, literatura cinza, Central de Registros de Ensaios Controlados Cochrane, o ISI Web of Science e IBECS do início de 1990 a junho de 2014. Nós relatamos os resultados usando risco relativo (RR) com intervalos de confiança de 95\%. A pesquisa bibliográfica encontrou 180 publicações potencialmente relevantes. Buscas nas listas de referência encontraram mais duas citações. Entre esses estudos, dois foram considerados elegíveis para inclusão nesta revisão. Ambos os ensaios incluíram 1.213 pacientes. Uma metanálise desses estudos mostrou um $\mathrm{RR}=0,77(95 \% \mathrm{CI}, 70-0,86 ; \mathrm{p}<0,001)$. Este resultado sugere que um tratamento precoce com a combinação de um antiviral e um esteróide é benéfico para o tratamento de herpes labial simplex.

Palavras-chave: aciclovir, herpes labial, hidrocortisona, ME-609, Revisão Sistemática.

\section{REFERENCES}

BALFOUR JR HH, BEAN B, LASKIN OL, AMBINDER RF, MEYERS JD AND WADE JC. 1983. Acyclovir halts progression of herpes zoster in immunocompromised patients. N Engl J Med 308: 1448-1453.

BraZzini B AND Pimpinelli N. 2002. New and established topical corticosteroids in dermatology: clinical pharmacology and therapeutic use. Am J Clin Dermatol 3: 47-58.

DeEKs JJ, HigGins JPT AND Altman DG. 2008. Analyzing data and undertaking meta-analysis. In: Higgings $J$ and Green S (Eds), Cochrane Handbook for systematic Reviews of Interventions 5.0.1. Oxford, UK: The Cochrane Collaboration, chapter 9.

DERSIMONIAN R AND LAIRD N. 1986. Meta-analysis in clinical trials. Control Clin Trials 7: 177-188.
ELION GB. 1982. Mechanism of action and selectivity of acyclovir. Am J Med 73: 7-13.

EMBIL JA, STEPHENS RG AND MANUEL FR. 1975. Prevalence of recurrent herpes labialis and aphthous ulcers among young adults on six continents. Can Med Assoc J 113: 627-630.

Evans TG, Bernstein Di, RABORn GW, HARMENBERG J, Kowalski J and Spruance SL. 2002. Doubleblind, randomized, placebo-controlled study of topical $5 \%$ acyclovir-1\% hydrocortisone cream (ME-609) for treatment of UV radiation-induced herpes labialis. Antimicrob Agents Chemother 46: 1870-1874.

FDA - FoOD AND DRUG Administration. 2012. Available at: http://www.accessdata.fda.gov/drugsatfda_docs/ nda/2009/022436s000_Lbl.pdf Accessed Jun 7, 2012.

Harmenberg JG, Awan AR, Alenius S, StÅhle L, ERLANDSSON AC AND LEKARE G. 2003. ME-609: a treatment for recurrent herpes simplex virus infections. Antivir Chem Chemother 14: 205-215.

Harmenberg J, OBerg B AND SPRUANCE S. 2010. Prevention of ulcerative lesions by episodic treatment of recurrent herpes labialis: A literature review. Acta Derm Venereol 90: 122-130.

Hull CM, Harmenberg J, Arlander E, Aoki F, Bring J, Darpö B, LeVIn MJ, Tyring S AND SPRUance SL. 2011. ME-609 Study Group. Early treatment of cold sores with topical ME-609 decreases the frequency of ulcerative lesions: a randomized, double-blind, placebo-controlled, patientinitiated clinical trial. J Am Acad Dermatol 64: 696. e1-11.

LASKIN OL. 1983. Clinical pharmacokinetics of acyclovir. Clin Pharmacokinet 8: 187-201.

Liberati A, Altman DG, Tetzlaff J, Mulrow C, Gøtzsche PC AND IOANNIDIS JP. 2009. The PRISMA statement for reporting systematic reviews and meta-analyses of studies that evaluate healthcare interventions: explanation and elaboration. BMJ 339: b2700.

REVIEW MANAGER. 2008. (RevMan) [Computer program] Version 5.0. Copenhagen: The Nordic Cochrane Centre, The Cochrane Collaboration.

SCIUBBA JJ. 2003. Herpes simplex and aphthous ulcerations: presentation, diagnosis and management--an update. Gen Dent 51: 510-516.

Spruance SL, Overall JR JC, Kern ER, Krueger GG, PliaM V AND MiLleR W. 1977. The natural history of recurrent herpes simplex labialis: implications for antiviral therapy. N Engl J Med 297: 69-75.

Wald A, ERICSSON M, Krantz E, SElKe S AND Corey L. 2004. Oral shedding of herpes simplex virus type 2 . Sex Transm Infect 80: 272-276.

Whitley RJ AND RoIZMAN B. 2001. Herpes simplex virus infections. Lancet 357: 1513-1518. 